\title{
PENGARUH PRINSIP KONSERVATISME AKUNTANSI TERHADAP MEKANISME GOOD CORPORATE GOVERNANCE DAN KUALITAS LABA PERUSAHAAN
}

\author{
Ismail 1) \\ ${ }^{1}$ Mahasiswa Program Doktor Ilmu Akuntansi Universitas Airlangga \\ email: ismail.unair.ak@gmail.com
}

(Diterima: 06-Januari-2018; di revisi: 08-Februari-2018; dipublikasikan: 18-April-2018)

\begin{abstract}
The purpose of this study was to examine the effect of accounting conservatism principle to good corporate governance mechanisms (using the approach of managerial ownership and composition of independent directors) and its effect on the quality of corporate profits, using the data of manufacturing companies in Indonesia Stock Exchange period 2011 - 2014. The method used data analyst in this research is Structural Equation Modeling (SEM). The results of this study showed that accounting conservatism have an influence on managerial ownership as a mechanism of good corporate governance and accounting conservatism affects the quality of corporate profits, it gives an understanding that managers would reduce accounting conservatism measures to improve the quality of corporate profits.
\end{abstract}

\section{Keywords: Conservatism Accounting, Corporate Governance, Earnings Quality}

\begin{abstract}
Abstrak:
Penelitian ini bertujuan untuk menguji pengaruh prinsip konservatisme akuntansi terhadap mekanisme good corporate governance (menggunakan pendekatan kepemilikan manajerial dan komposisi komisaris independen) dan pengaruhnya terhadap kualitas laba perusahaan, menggunakan data perusahaan manufaktur di Bursa Efek Indonesia periode 2011 - 2014. Metode analis data yang digunakan dalam penelitian ini adalah Structural Equation Modeling (SEM). Hasil penelitian ini menujukkan bahwa konservatisme akuntansi mempunyai pengaruh terhadap kepemilikan manajerial sebagai mekanisme Good Corporate Governance dan konservatisme akuntansi berpengaruh terhadap kualitas laba perusahaan, hal ini memberikan pemahaman bahwa manajer akan mengurangi tindakan konservatisme akuntansi untuk meningkatkan kualitas laba perusahaan.
\end{abstract}

Kata Kunci : Konservatisme Akuntansi, GCG, Kualitas Laba

\section{PENDAHULUAN}

$$
\text { Prinsip konservatisme akuntansi }
$$
merupakan prinsip kehati-hatian perusahaan dalam melaporkan posisi keuangan. Hal ini memberikan dampak terhadap perusahaan karena tidak terlalu cepat mengakui laba ataupun kerugian yang dialami perusahaan. Sehingga, prinsip ini menekankan agar mengukur aktiva dan laba lebih rendah dan melaporkan kewajiban lebih besar. Konsep dan prinsip konservatisme banyak diterapkan oleh perusahaan sehingga membuat investor cenderung meragukan atas kualitas informasi akuntansi yang dilaporkan oleh perusahaan. Menurut Lin et.al (2014) menyatakan bahwa Konservatisme akuntansi adalah ukuran untuk membatasi terjadinya risiko atas laporan keuangan. 
Ismail, Pengaruh Prinsip Konservatisme Akuntansi Terhadap Mekanisme Good Corporate Governance Dan Kualitas Laba Perusahaan.|19

Informasi akuntansi dapat juga dikatakan sebagai informasi ekonomi, harus diakui secara formal bahwa beberapa pihak dalam transaksi keuangan seringkali mempunyai keunggulan informasi dibandingkan dengan pihak lain. Hal ini disebut sebagai asimetri informasi. Menurut Scoot (2000) terdapat dua jenis asimetri informasi yaitu adverse selection dan moral hazard.Adverse selection terjadi ketika beberapa orang dalam seperti manajer perusahaan dan orang dalam lainnya mengetahui lebih banyak informasi mengenai kondisi perusahaan saat ini dan prospek masa depan perusahaan tersebut dibandingkan dengan pihak luar perusahaan (investor). Sedangkan moral hazard muncul dalam banyak situasi, dalam konteks ini moral hazad terjadi karena dipisahkannya kepemilikan dan pengendalian yang merupakan ciri perusahaan besar. Secara efektif tidak mungkin para pemegang saham dan kreditor mengamati langsung cukupan dan kualitas upaya manajer puncak demi kepentingan mereka.

Munculnya masalah-masalah keagenan didasarkan pada dua asumsi, yaitu: (1) Manajer akan bertindak untuk kepentingan dirinya sendiri dengan menggunakan uang perusahaan atau fasilitas-fasilitas yang tersedia lainnya. (2) Manajer memiliki akses informasi yang lebih baik daripada pemengang saham, atau adanya asimetri informasi antara pemilik dan manajer.Konflik kepentingan memunculkan biaya keagenan (agency cost) sehingga masingmasing pihak akan berusaha mengurangi biaya tersebut. Selain terdapat konflik eksternal, ada pula konflik internal didalam agen maupun prinsipal sendiri. Konflik kepentingan berpotensi menimbulkan masalah-masalah keagenan atau menimbulkan biaya keagenan seperti yang diungkapkan oleh Jensen dan Meckling (1976).Hubungan keagenan merupakan dasar yang digunakan untuk memahami corporate governance.

Secara umum mekanisme corporate governance dapat diklasifikasikan ke dalam dua kelompok. Pertama, adalah mekanisme internal spesifik perusahaan yang terdiri atas stuktur kepemilikan dan struktur pengelolaan. Kedua, adalah mekanisme eksternal spesifik negara yang terdiri atas aturan hukum dan dasar pengendalian perusahaan (Lins dan Karl 2003). Dalam penelitian ini mekanisme corporate governance akan berkaitan dengan kepemilikan oleh manajemen dan komposisi komisaris yang independen. Dari semua informasi tentang perusahaan yang tersedia sepanjang tahun, sebagian atau bahkan lebih diperoleh dari angka laba (income numbers) dalam tahun yang bersangkutan (Ball dan Brown, 1968). Kualitas laba yang dilaporkan dapat dipengaruhi oleh kepemilikan saham manajerial. Kepemilikan saham manajerial merupakan salah satu unsur Good Corporate Governance (GCG). Tekanan dari pasar modal menyebabkan perusahaan dengan kepemilikan manajerial yang rendah akanmemilih metode akuntansi yang meningkatkan laba yang dilaporkan, yang sebenarnya tidak mencerminkan keadaan ekonomi dari perusahaan yang bersangkutan (Boediono, 2005). Atas dasar hal ini maka peneliti memasukkan Good Corporate Governance (GCG) sebagai variabel yang turut mempengaruhi hubungan konservatisma akuntansi dan informasi asimetri terhadap kualitas laba akrual. 
Jensen dan Meckling (1976) menyatakan bahwa hubungan keagenan adalah sebuah kontrak antara manajer (agent) dengan investor (principal). Konflik kepentingan antara pemilik dan agen terjadi karena kemungkinan agen tidak selalu berbuat sesuai dengan kepentingan prinsipal, sehingga memicu biaya keagenan (agency cost).Jensen dan Meckling (1976) menyatakan bahwa jika kedua kelompok (agent dan principal) tersebut adalah orang-orang yang berupaya memaksimalkan utilitasnya, maka alasan yang kuat untuk meyakini bahwa agen tidak akan selalu bertindak yang terbaik untuk kepentingan prinsipal. Jensen dan Meckling (1976) mengidentifikasi kos keagenan menjadi tiga kelompok, yaitu :1) the monitoring expenditure by the principal adalah kos pengawasan yang harus dikeluarkan oleh pemilik; 2) the bonding cost adalah kos yang harus dikeluarkan akibat adanya biaya pengawasan yang harus dikeluarkan principal kepada agen; 3) the residual loss adalah pengorbanan akibat berkurangnya kemakmuran prinsipal karena perbedaan keputusan antara prinsipal dengan agen.

Secara umum laba merupakan selisih antara pendapatan dikurangi dengan biaya yang dikeluarkan oleh perusahaan. Adanya informasi laba yang dilaporkan oleh manajemen akan memberikan informasi yang berguna baik pihak internal maupun pihak ekstrenal. Pengukuran laba menunjukkan seberapa besar kinerja perusahaan dalam menjalankan kegiatannya. informasi laba merupakan salah satu informasi untuk mengetahui perkembangan perusahaan, selain itu informasi yang pertama kali ingin diketahui oleh investor dalam melakukan investasi adalah laba yang diperoleh perusahaan selama beberapa periode karena dengan informasi laba, investor mampu melihat kinerja perusahaan untuk masa yang akan datang. Oleh karena itu pihak manajemen dalam memberikan informasi laba terkadang melakukan modivikasi laporan keuangan agar memberikan informasi laba yang besar dalam laporan keuangan. Menurut Donnelly (1990), kualitas laba menentukan seberapa besar laba yang dipublikasikan oleh perusahaan menyimpang dari laba operasi yang sesungguhnya. Kualitas laba yang tinggi berarti kualitas laba yang menggambarkan prospek usaha dan sikap manajemen yang realistis dalam memandang keadaan usahanya. Sebuah perusahaan yang melaporkan penurunan kualitas laba dapat diartikan bahwa manajemen memiliki prospek yang lebih buruk daripada kinerja sebelumnya.

Nilai perusahaan mencerminkan seberapa besar aktivitas perusahaan mulai dari berdirinya hingga aktivitas saat ini. Nilai perusahaan yang besar akan memberikan kesejahteraan bagi pihak manajemen dan pihak pemengang saham. Oleh karena itu nilai perusahaan juga merupakan faktor yang dipertimbangkan investr dalam melakukan investasi. Penelitian yang dilakukan oleh Hamonangan Siallagan (2009) menguji Pengaruh Kualitas Laba Terhadap Nilai Perusahaan, hasil penelitiannya menyatakan bahwa Kualitas Laba secara positif berpengaruh terhadap Nilai Perusahaan. Akrual diskresioner yang digunakan sebagai proksi Kualitas Laba secara negatif berpengaruh terhadap nilai perusahaan. Semakin kecil akrual diskresioner 
Ismail, Pengaruh Prinsip Konservatisme Akuntansi Terhadap Mekanisme Good Corporate Governance Dan Kualitas Laba Perusahaan. | 21

(mengindikasikan laba berkualitas) maka nilai perusahaan semakin tinggi.

Penelitian ini bertujuan untuk mendapatkan bukti secara empris mengenai pengaruh prinsip konservatisme akuntansi, good corporate governance terhadap kualitas laba perusahaan. Teori yang digunakan untuk mendukung penelitian ini adalah menggunakan teori keagenan yang diperkenalkan oleh Jansen dan Macklin tahun 1976. Teori agensi menyatakan bahwa apabila terdapat pemisahan antara pemilik sebagai principal dan manajer sebagai agen yang menjalankan perusahaan maka akan muncul permasalahan agensi karena masing-masing pihak tersebut akan selalu berusaha untuk memaksimalisasikan fungsi utilitasnya (Jensen dan Meckling, 1976). Agen memiliki informasi yang lebih banyak dibandingkan dengan prinsipal, sehingga menimbulkan adanya asimetri informasi yaitu suatu kondisi adanya ketidakseimbangan perolehan informasi antara pihak manajemen sebagai penyedia informasi dengan pihak pemegang saham dan stakeholder sebagai pengguna informasi.

Konservatisme dapat dijelaskan dari perspektif teori keagenan. Teori tersebut menyatakan perusahaan merupakan nexus of contract yakni tempat bertemunya kontrak antar berbagai pihak yang berpotensi menimbulkan konflik kepentingan. Konflik tersebut tercermin dari kebijakan dividen, pendanaan, dan kebijakan investasi (Jensen and Meckling 1976). Ketiga kebijakan tersebut dapat digunakan oleh investor untuk mengatur manajer dan mentransfer keuntungan dari kekayaan kreditor. Upaya investor tersebut akan menjadi lebih sulit dengan adanya laporan keuangan yang konservatif. Konservatisme akuntansi akan mendukung terciptanya kontrak yang efisien antara berbagai pihak, khususnya pihak investor dan kreditor sebagai pengguna utama laporan keuangan.

Beberapa penelitian tentang konservatisme telah dilakukan seperti penelitian yang dilakukan oleh Chi et al. (2009) menguji tentang hubungan konservatisme akuntansi dengan Good Corporate Governance, hasil penelitiannya menemukan bahwa terdapat hubungan yang negatif antara konservatisem akuntansi dengan Good Corporate Governanceartinya bahwa pengelolaan perusahaan yang baik akan mengurangi tindakan konservatisme akuntansi. Penelitian Lin et al. (2014) menguji tentang konservatisme akuntansi, investor sebagai pemegang saham dan manupulasi laba perusahaan, hasil penelitiannya menunjukkan bahwa perusahaan dengan pelaporan keuangan yang lebih konservatif memiliki probabilitas kurang terlibat dalam manupulasi laba. Penelitian ini juga menemukan hubungan negatif antara manajemen laba dan kepemilikan saham investor institusional. Namun, jika laporan keuangan perusahaan cenderung ke arah konservatisme, kepemilikan saham investor institusional dapat meningkatkan insentif manajer untuk melakukan manajemen laba. Temuan penelitin ini memiliki implikasi penting bagi investor untuk membuat keputusan investasi.

Manganarisa et al. (2015) meneliti tentang hubungan antara nilai relevansi informasi akuntansi dan syarat konservatisme pada sektor perbankan di Eropa dengan menggunakan IFRS, hasil penelitiannya menemukan bahwa syarat konservatisme adalah positif terkait untuk nilai 
relevansi sebelum mengadopsi IFRS dan memporeh nilai negatif setelah mengadopsi IFRS. Penelitian ini juga membuktikan bahwa relevansi nilai dapat menurunkan konservatisme dan hubungan konservatisme dengan relevansi nilai tergantung pada karakteristik institusional tertentu. Penelitian yang dilakukan Goh dan Li (2011) meneliti tentang internal control konservatisme akuntansi hasil penelitiannya menemukan bahwa perusahaan-perusahaan yang mengungkapkan kelemahan material (MWs) menunjukkan konservatisme bersyarat rendahdari perusahaan tanpa kelemahan tersebut, dan MW perusahaan yang memulihkankelemahan menunjukkan konservatisme yang lebih besar dari perusahaanperusahaan MW yang gagal untuk melakukannya. Secara kolektif, hasil penelitian konsisten dengan kontrol internal yang kuat sehingga memfasilitasi konservatisme.

Kontribusi penelitian ini adalah diharapkan hasil penelitan ini dapat menjadi informasi dan tambahan wawasan yang bermanfaat khususnya mengenai penerapan sistem akuntansi konservatif sebagai sinyal untuk meningkatkan kualitas laba perusahaan.Hasil penelitian ini juga dapat menjadi informasi yang bermanfaat bagii para pembaca khususnya investor dan manajemen perusahaan mengenai penerapan konservatisma dalam pembuatan laporan keuangan dan bagaimana informasi asimetri dapat dikurangi sehingga dapat meningkatkan kualitas laba.Hasil penelitian ini diharapkan dapat memberikan informasi kepada manajer dan investor sebagai salah satu pihak decison making dalam perusahaan dan pihak lainnya, mengenai sejauh mana konservatisma dapat diterapkan dalam sistem pelaporan keuangan

Lain halnya yang dilakukan oleh Zhang (2007) meneliti tentang manfaat konservatisme akuntansi bagi peminjam dan pemberi pinjaman, hasil penelitiannya menyatakan bahwa peminjam dan nilai pemberi pinjaman konservatisme, sebagai konservatisme memberikan lender sinyal lebih tepat waktu dari risiko default dan peminjam suku bunga yang lebih rendah. Peneliti juga menemukan bahwa peminjam yang lebih konservatif lebih cenderung melanggar perjanjian setelah guncangan harga negatif, danbahwa pemberi pinjaman menurunkan suku bunga mereka tetapkan untuk peminjam konservatif yang keemungkinan lebih tinggi dari perjanjianpelanggaran dan suku bunga yang lebih rendah menunjukkan bahwa konservatisme menguntungkan baik pemberi pinjaman dan peminjam,meningkatkan efisiensi kontrak utang.

Pada penelitian yang dilakukan oleh Gabrielsen et al (1997) menguji hubungan antara kepemilikan manajerial dan kandungan informasi laba serta discretionary accrual. Dengan menggunakan data pasar modal Denmark, ditemukan adanya hubungan yang positif tetapi tidak signifikan antara kepemilikan manajerial dan discretionary accrual dan hubungan negatif antara kepemilikan manajerial dan kandungan informasi laba, menemukan bukti bahwa kepemilikan manajerial berhubungan secara negatif dengan discretional accruals. Hasil penelitian ini juga menyatakan bahwa kualitas laba meningkat ketika kepemilikan manajerial juga tinggi. 
Ismail, Pengaruh Prinsip Konservatisme Akuntansi Terhadap Mekanisme Good Corporate Governance

Dan Kualitas Laba Perusahaan. | 23

Penelitian mengenai ukuran dewan direksi (Vafeas, 1998) menyimpulkan bahwa semakin kecil ukuran dewan direksi maka akan semakin baik dalam pelaksanaan monitoring terhadap manajemen perusahaan akan tetapi, Chtourou et al (2001) memberikan hasil yang berlawanan dimana semakin besar ukuran dewan direksi maka akan semakin baik proses monitoring terhadap manajemen perusahaan. Dari beberapa penelitian yang ditelaah, khususnya dari penelitian Mayangsari dan Wilopo, 2002, dimana, penelitian mereka membuktikan bahwa laba dan aktiva yang dihitung dengan akuntansi konservatif maka akan dapat meningkatkan kualitas laba, maka pada penelitian ini penulis akan menambahkan variabel informasi asimetri, apakah mempunyai pengaruh terhadap kualitas laba akrual, yang mana dimoderasi oleh Good Corporate Governance (GCG).

Di Indonesia penelitian konservatif yang dilakukan oleh Fuad (2012) meneliti tentang dampak konservatisme akuntansi dan struktur kepemilikan terhadap relevansi informasi akuntansi. Hasil penelitiannya menemukan bahwa perusahaan yang kepemilikannya didominasi oleh korporat memiliki kandungan informasi return yang lebih informatif karena lebih dapat memprediksi profitabilitas. Disamping itu, hasil penelitian ini juga menunjukkan bahwa kandungan informasi return lebih cepat terjadi pada perusahaan yang memiliki kebijakan akuntansi lebih konservatif daripada yang kurang konservatif. Nurhayati (2011) meneliti tentang Pengaruh Konservatisme Akuntansi terhadap Nilai Perusahaan Dimoderasi oleh Good Corporate Governance, menyimpulkan bahwa konservatisme akuntansi tidak berpengaruh secara signifikan terhadap nilai perusahaan. Hal tersebut berarti bahwa pasar tidak menerima sinyal tentang penerapan konservatisme akuntansi dalam perusahaan dan menilai lebih dengan memberikan premium tinggi bagi harga saham perusahaan tersebut.

Berdasarkan beberapa hasil penelitian tersebut diatas dan teori yang mendukung maka masalah dalam penelitian ini adalah: (1) Apakah prinsip konservatisme akuntansi berpengaruh signifikan terhadap kualitas laba perusahaan? (2) Apakah konservatisme akuntansi berpengaruh terhadap kualitas laba perusahaan melalui mekanisme Good Corporate Governanceyang terdiri dari kepemilikan manajerial dan komposisi dewan komisaris.

Penelitian ini dilakukan pada perusaahaan yang terdaftar di Bursa Efek Indonesia dengan menggunakan data time series dengan banyak perusahaan (cross section). Penelitian ini menggunakan beberapa variabel yaitu konservatisme akuntansi, good corporate governance dan kualitas laba perusahaan yang diperoleh melalui kajian teoritis dan empiris yang dilakukan peneliti. Jenis data yang digunakan dalam penelitian ini adalah data kuantitatif, yaitu data yang berbentuk angkaangka atau data kualitatif yang diangkakan (Sugiyono, 2006).

Penelitian ini diharapkan memberikan informasi dan tambahan wawasan yang bermanfaat khususnya mengenai penerapan sistem akuntansi konservatif sebagai sinyal untuk meningkatkan kualitas laba perusahaan. Selain itu diharapkan dapat dapat memberikan informasi kepada manajer dan investor sebagai salah satu pihak decison making dalam 
perusahaan dan pihak lainnya, mengenai sejauh mana konservatisma dapat diterapkan dalam sistem pelaporan keuangan serta dapat mempertimbangakan sistem informasi yang lebih transparan, sehingga dapat mengurangi informasi asimetri kepada pihak-pihak yang berkepentingan. Kontribusi dalam penelitian ini adalah menguji konservatisme akuntansi, Good Corporate Governance dan kualitas laba perusahaan dengan menggunakan data terbaru pada perusahaan yang terdaftar di Bursa Efek Indonesia, selain itu, penelitian ini memberikan gambaran tentang fenomena konservatisme akuntansi di Indonesia.

\section{METODE}

\section{Pendekatan Penelitian}

Penelitian ini menggunakan pendekatan penelitian kuantitatif. Pendekatan kuantitatif merupakan penelitian dengan cara mengumpulkan data dalam bentuk angka-angka yang diperoleh pada saat melakukan penelitian. Pendekatan ini akan membantu peneliti menguji pokok permasalahan yang dijelaskan sebelumnya.

\section{Deskripsi Fokus Penelitian}

Penelitian ini menguji beberapa variabel yang pengaruh konservatisme akuntansi, good corporate governance terhadap kualitas laba perusahaan. Pengukuran variabel dalam penelitian ini adalah sebagai berikut:

a. Konservatisme akuntansi menggunakan pengukuran model Zhang tahun 2007

$$
\operatorname{CONACC}_{i t}=\left(\mathrm{NI}_{\mathrm{it}}-\mathrm{CFO}_{\mathrm{it}}\right) \mathrm{x}-1
$$

Keterangan:
CONACC $_{i t}$ : Konservatisma perusahaan i pada tahun $\mathrm{t}$

$\mathrm{NI}_{\text {it }} \quad$ : Laba bersih perusahaan i pada tahun $\mathrm{t}$

$\mathrm{CFO}_{\text {it }} \quad$ : Arus kas kegiatan operasi perusahaan i pada tahun $\mathrm{t}$

b. Mekanisme Good Corporate Governance menggunakan indikator kepemilikan manajerial dan komisaris independen

Kepemilikan manajerial merupakan kesejajaran kepentingan antara manajemen dan pemegang saham (outsiders ownnership), sehingga akan memperoleh manfaat langsung dari keputusan yang diambil serta menanggung kerugian sebagai konsekuensi dari pengambilan keputusan yang salah.Kepemilikan manajerial dapat dihitung dengan besarnya persentase saham yang dimiliki oleh pihak manajemen perusahaan. Pemilik manajerial merupakan pemegang saham yang berasal dari pihak manajemen, yang mana disamping sebagai pengelola juga dapat berperan serta dalam pengambilan keputusan.Rumus yang digunakan adalah :

Jumlah Saham yang dimiliki Direktur dan Komisaris x 100\% Jumlah Saham Independen Komisaris independen adalah komisaris yang tidak mempunyai kepentingan internal di perusahaan. Informasi mengenai jumlah komisaris independen ini akan diperoleh dari laporan tahunan masing-masing perusahaan. Komposisi komisaris independen dapat dihitung dengan :

Jumlah Komisaris Independen x 100\%

Jumlah Komisaris

c. Kualitas laba menggunakan pengukuran discretionary accrual 
Ismail, Pengaruh Prinsip Konservatisme Akuntansi Terhadap Mekanisme Good Corporate Governance Dan Kualitas Laba Perusahaan. | 25

\section{$\mathrm{TAC}_{\text {it }}=\mathrm{NI}_{\mathrm{it}}-\mathrm{CFO}_{\text {it }}$}

Keterangan :

$\mathrm{TAC}_{\mathrm{it}}$ : Total accruals perusahaan $\mathrm{i}$ pada tahun $\mathrm{t}$ $\mathrm{NI}_{\text {it }}$ : laba bersih perusahaan i pada tahun $\mathrm{t}$ $\mathrm{CFO}_{\text {it }}$ : Arus kas kegiatan operasi perusahaan i pada tahun $\mathrm{t}$.

\section{Populasi dan Sampel}

Populasi yang digunakan dalam penelitian ini adalah seluruh perusahaan yang terdaftar di Bursa Efek Indonesia dari tahun 2011-2014. Sedangkan sampel dalam penelitian ini adalah perusahaan yang memenuhi kriteria-kriteria tertentu (Purposive random sampling) yang terdiri dari: (1) Memiliki laporan keuangan yang telah diaudit oleh akuntan publik untuk tahun yang berakhir 31 desember selama periode pengamatan penelitian, yaitu dari tahun 2011 hingga tahun 2014. (2) Perusahaan yang minimal memiliki data laporan keuangan yang diaudit serta data mengenai mekanisme Good Corporate Governance (3) data yang menggabarkan harga saham yang tersedia selama perioda estimasi dan pengamatan.

\section{Metode Pengumpulan Data}

Metode pengumpulan data dalam penelitian ini yakni jawaban dari kuesioner yang diisi responden yang terpilih sebagai sampel dan persepsi seseorang atau sekelompok orang tentang fenomena sosial. Alternatif jawaban setiap instrument yang menggunakan skala likert mempunyai gradasi dari sangat positif sampai sangat negatif.

\section{Bahan dan Alat Utama}

Data sekunder adalah sumber data dalam penelitian ini adalah yaitu sebagai interpretasi dari data primer (Cooper dan Schindler, 2006).
Sumber data penelitian merupakan faktor penting yang menjadi pertimbangan dalam penentuan metode pengunpulan data. Sumber data penelitian terdiri atas sumber data primer dan sumber data sekunder (Indriantoro dan Supomo, 2011). Data dalam penelitian ini diperoleh peneliti secara tidak langsung melalui media perantara (diperoleh dan dicatat oleh pihak lain) berupa bukti, catatan atau laporan historis yang telah tersusun dalam arsip (data dokumenter) yang dipublikasikan. Data diperoleh dari laporan keuangan tahunan perusahaan yang terdaftar di Bursa Efek Indonesia dan ICMD dari tahun 2011 hingga 2014. Data yang diperoleh di analisis sesuai dengan variabel yang digunakan dalam penelitian ini.

\section{Metode Analisis Data}

Analisis data penelitian yang merupakan bagian dari proses pengujian data setelah tahap pemilihan dan pengumpulan data penelitian. Proses analisis data penelitian umumnya terdiri atas beberapa tahap yaitu: tahap persiapan, analisis deskriktif, pengujian kualitas data dan pengujian hipotesis.Metode analis data yang digunakan dalam penelitian ini adalah Structural Equation Modeling (SEM). Structural Equation Modeling (SEM) merupakan suatu alat statistik yang digunakan untuk menyelesaikan model empirik serempak yang tidak dapat diselesaikan oleh persamaan regresi linear. SEM dapat juga dianggap sebagai gabungan dari analisis regresi dan analisis faktor. SEM dapat dipergunakan untuk menyelesaikan model persamaan dengan variabel terikat lebih dari satu dan juga pengaruh timbal balik (recursive). SEM berbasis pada analisis covarians sehingga memberikan matriks 
covarians yang lebih akurat dari pada analisis regresi linear. Program-program statistik yang dapat dipergunakan untuk menyelesaikan SEM misalnya Analysis Moment of Structure (AMOS) atau LISREL. SEM mampu menyelesaikan model yang rumit yang sering muncul dalam dunia pemasaran atau bidang konsentrasi yang lain. Model yang akan diselesaikan dengan SEM harus mempunyai dasar teori yang kuat, karena SEM tidak dapat digunakan untuk menyelesaikan model kausalitas imaginer.

\section{HASIL DAN PEMBAHASAN}

Hasil pengujian goodness-of-fit terhadap model penelitian seperti pada tabel 1 menujukkan bahwa full model dapat diterima.

\section{Tabel 1. Ringkasan Indeks goodness-}

of-fit model penelitian

\begin{tabular}{|c|c|c|c|}
\hline $\begin{array}{c}\text { Goodness of } \\
\text { Fit Index }\end{array}$ & $\begin{array}{l}\text { Cut-off } \\
\text { Value }\end{array}$ & $\begin{array}{c}\text { Hasil } \\
\text { Analisis }\end{array}$ & Ket \\
\hline \multicolumn{4}{|l|}{ Degree of } \\
\hline \multicolumn{4}{|l|}{ Fredom } \\
\hline $\begin{array}{l}\text { Probabilility } \\
\text { (P) }\end{array}$ & $\geq 0,05$ & 0,063 & Baik \\
\hline $\begin{array}{l}\text { Absolute Fit } \\
\text { Measure }\end{array}$ & & 3,457 & Baik \\
\hline \multicolumn{4}{|l|}{ Incremental } \\
\hline \multicolumn{4}{|l|}{ Fit Measure: } \\
\hline - $\quad$ TLI & $\geq 0,95$ & 0,967 & Baik \\
\hline - $\quad$ CFI & $\geq 0,95$ & 0,997 & Baik \\
\hline
\end{tabular}

Sumber : Hasil olah data

Dari perhitungan assesment of normality, diketahui bahwa data memiliki distribusi normal, karena nilai Critical Ratio (C.R) tidak melebihi nilai 2,58 yang artinya distribusi data penelitian tidak normal pada tingkat signifikan $5 \%$. Hasil analisis juga diketahui tidak terdapat mahalanobis distance yang lebih besar dari
54,79. Dengan demikian dapat disimpulkan data penelitian tidak mengandung multivariate outliers. Hasil ouput AMOS 4.0 menunjukkan nilai determinan matriks kovarians sebesar 6,683 yang jauh dari angka nol. Secara keseluruhan ringkasan perhitungan regression weights dijelaskan pada tabel 2 berikut ini:

Tabel 2. Ringkasan Estimasi Parameter Model Persamaan Struktul Penelitian

\begin{tabular}{lcc}
\hline \multicolumn{1}{c}{$\begin{array}{c}\text { Pengaruh } \\
\text { variabel }\end{array}$} & Estimate & $\begin{array}{c}\text { Standardized } \\
\text { Estimate }\end{array}$ \\
\hline $\begin{array}{l}\text { GCG1<------- } \\
\text { CON_ACC }\end{array}$ & $-0,390$ & $-0,278$ \\
GCG2<------- & $-0,281$ & $-0,196$ \\
CON_ACC & $-0,996$ & $-0,999$ \\
EARNING<-- & & \\
CON_ACC & 0,003 & 0,004 \\
EARNING<---- & & $-0,001$ \\
----GCG1 & 0,000 & \\
EARNING<---- & & \\
-----GCG2 &
\end{tabular}

Sumber : Hasil olah data

Hasil pengujian statistik pada tabel 2 diatas menujukkan bahwa konservatisme akuntansi mempunyai pengaruh terhadap kepemilikan manajerial sebagai mekanisme Good Corporate Governance, nilaistandardized estimate sebesar -0,279dan probabilitas sebesar 0,026 yang lebih rendah dari 0,05 artinya bahwa kepemilikan manajerial dapat mengurangi tindakan konservatisme akuntansi. Hasil penelitian ini mendukung penelitian yang dilakukan oleh Chi et.al (2009) menguji tentang hubungan konservatisme akuntansi dengan Good Corporate Governance, hasil penelitiannya menemukan bahwa terdapat hubungan yang negatif antara konservatisem akuntansi dengan Good Corporate Governanceartinya bahwa pengelolaan perusahaan yang baik akan mengurangi tindakan konservatisme akuntansi. 
Ismail, Pengaruh Prinsip Konservatisme Akuntansi Terhadap Mekanisme Good Corporate Governance

Dan Kualitas Laba Perusahaan. | 27

Pengujian tentang pengaruh konservatisme akuntansi terhadap komposisi komisaris independen sebagai mekanisme Good Corporate Governance diperoleh nilai standardized estimate sebesar -0,196dan probabilitas sebesar 0,125 yang lebih besar dari 0,05 artinya bahwa tidak terdapat pengaruh yang signifikan antara konservatisme akuntansi terhadap komposisi komisaris independen. Hal ini dikarenakan adanya kendali dari manajemen sebagai pendiri perusahaan yang membuat kemampuan komisaris independen dalam menjalankan fungsi pengawasan menjadi tidak efektif. Hasil ini juga diperkuat dengan pendapat Siregar dan Utama (2006) yang menyatakanbahwa pengangkatan dewan komisaris independenoleh perusahaan mungkin hanya dilakukan untukmemenuhi regulasi saja dan tidak dimaksudkanuntuk menegakkan Good Corporate governancedalam perusahaan.

Hasil pengujian menunjukkan bahwa nilai standardized estimate sebesar -0,999dan probabilitas sebesar 0,000 yang lebih rendah dari 0,05 artinya bahwa terdapat pengaruh yang singnifikan antara konservatisme akuntansi terhadap kualitas laba. Hal ini menunjukkan bahwa apabila manajemen melakukan konservatisme akuntansi maka kualitas laba perusahaan cenderung mengalami penurunan. Hasil penelitian ini mendukung penelitian yang dilakukan oleh Penman dan Zang (2002) yang meneliti tentang konservatisme akuntansi, kualitas laba dan return saham, hasil penelitiannya menemukan bahwa perusahaan yang menerapkan akuntansikonservatif dan pertumbuhan investasi temporerakan menghasilkan tingkat pengembalian yangtemporer atau laba yang berfluktuasi dan hal inimembuat kualitas laba menjadi rendah.

Hasil analisis data pada tabel 2 diatas menunjukkan bahwa tidak terdapat pengaruh yang signifikan antara kepemilikan manajerial dan komposisi komisaris independen sebagai mekanisme Good Corporate Governance terhadap kualitas laba perusahaan. Nilai standardized estimate masing-masingsebesar 0,004 dan -0,001, nilai probabilitas masingmasing sebesar 0,237 dan 0,882yang lebih besar dari 0,05. Hal ini memberikan bukti bahwa kepemilikan manajerial dan komposisi komisaris independen tidak terlibat langsung dalam mengukur kualitas laba perusahaan. Hasil penelitian ini sejalan dengan penelitian yang dilakukan oleh Gabrielsen et al (1997) yang menguji tentang hubungan antara kepemilikan manajerial dan kandungan informasi laba serta discretionary accrual. Hasil penelitiannya menemukan adanya hubungan yang positif tetapi tidak signifikan antara kepemilikan manajerial dan discretionary accrual dan hubungan negatif antara kepemilikan manajerial dan kandungan informasi laba. Hasil penelitian ini juga menyatakan bahwa kualitas laba meningkat ketika kepemilikan manajerial juga tinggi.

\section{KESIMPULAN DAN SARAN}

Penelitian ini membukitikan bahwa konservatisme akuntansi mempunyai pengaruh terhadap kepemilikan manajerial sebagai mekanisme Good Corporate Governance dan konservatisme akuntansi terhadap kualitas laba perusahaan, hal ini memberikan pemahaman bahwa manajer akan mengurangi tindakan konservatisme akuntansi untuk meningkatkan 
kualitas laba perusahaan. Namun hasil penelitian ini juga tidak dapat memberikan bukti empirik tentang pengaruh konservatisme akuntansi terhadap komposisi komisaris independen sebagai mekanisme Good Corporate Governance ini disebabkan karena kemungkinan pembentukan komisaris independen hanya sebagai frame dalam meningkatkan kinerja perusahaan. Penelitian ini juga tidak dapat membuktikan pengaruh kepemilikan manajerial dan komposisi komisaris independen, mungkin karena mekanisme Good Corporate Governannce bukan satu-satunya ukuran untuk menjamin kualitas laba perusahaan melainkan komponen lain, misalnya rasio keuangan.

Temuan empirik ini membawa implikasi teoritik bahwa untuk meningkatkan dan menjamin kualitas laba perusahaan sebaiknya menggunakan metode akuntansi yang sesuai GAAP agar tidak terjadi konservatisme akuntansi dan atau manajemen laba perusahaan yang dapat menurungkan kualitas laba. Hasil penelitian ini juga memberikan implikasi bagi pihak manajer agar mempertimbangkan komponen yang dapat menjamin kualitas laba perusahaan, tindakan manajer dalam melakukan konservatisme akuntansi dapat menurunkan kualitas laba perusahaan. Penelitian berikutnya diharapkan tetap mempertimbangkan konservatisme akuntansi dan mekanisme Good Corporate Governance dalam menguji pengaruh terhadap kualitas laba perusahaan dengan memasukkan seluruh komponen GCG serta menambahkan variabel lain misalnya, rasio keuangan dan persepsi investor terkait kualitas laba perusahaan.

\section{DAFTAR RUJUKAN}

Ahmed, A.S., Duellman, S. (2007). Accounting conservatism and board of director characteristics: An empirical analysis. Journal of Accounting and Economic.

Anthony, Robert N. dan Vijay Govindarajan, (2005), Sistem Pengendalian Manajemen (Terjemahan). Salemba Empat, Jakarta.

Arifin. (2005). Tinjauan Perspektif Teori Keagenan (Agency Theory), Pidato Pengusulan Jabatan Guru Besar Universitas Diponegoro.Semarang.

Ball R. Dan P.Brown. (1968). An Empirical Evaluation of Accounting Number. Journal of Accounting Research, Autumn.

Belkaoui, Ahmed Riahi. (2006). Teori Akuntansi, Edisi Kelima, Salemba Empat: Jakarta.

Bernard, V. L., dan T. S. Stober. (1989). The Nature and Amount of Information Reflected in Cash Flows and Accruals. The Accounting Review(October).

Bigelli M, Juan Francisco and F. Javier SánchezVidal, (2014), Financial Conservatism of Private Firms, Journal of Business Research

Bodie, Z., Kane, A., Marcus, Alan J. (2001). Essentials of Investment (4th edition). USA : prentice Hall.

Boediono, Gideon S. B. (2005). Kualitas Laba : Studi Pengaruh Mekanisme Corporate Governance dan Dampak Manajemen Laba dengan menggunakan Analisis Jalur. Simposium Nasional Akuntansi VIII: Solo.

Chi. W, Liu. C and Wang. T, (2009), What Effects Accounting Conservatism: A Corporate Governance Perspective, Journal of Contemporary Accounting \& Economics 5 (2009) 47-59.

Deni Darmawati, Khomsiyah dan Rika Gelar Rahayu. (2004). Hubungan Corporate Governance dan Kinerja Perusahaan. Simposium Nasional Akuntansi VII: 2004.

Fuad, (2012) Dampak Konservatisme Akuntansi dan Struktur Kepemilikan Terhadap Relevansi Informasi Akuntansi, Jurnal Akuntansi \& Auditing, Volume 9/no.1/november 2012: 1-96 Universitas Dipanegoro

France, J., LaFond, R, Olsson, P.M, \& Schipper, K. (2004). Cost of Equity and Earning Attributes. The Accounting Review, 9671010 
Gabrielsen, Gorm., Jeffrey D. Gramlich dan Thomas Plenborg. (1997). Managerial Ownership, Information Content of Earnings, and Discretionary Accruals in a Non-US Setting. Journal of Business Finance and Accounting, Vol.29. No.7 \& 8 . September/ Oktober

Indriantoro. N, Supomo. B, (2011) Metode Penelitian Bisnis untuk Akuntansi dan Manajemen. Edisi Pertama. Fakultas Ekonomi dan Bisnis UGM Yogyakarta.

Jensen Mc., dan Meckling W.H. (1976). Theory of the Firm: Managerial Behaviour, gency Cost and Ownership Structure.Journal of Financial economics 3(4): 305-360.

Kravet. D T, (2014) Accounting Conservatism and Managerial Risk-Taking : Corporate Acquisitions, Journal of Accounting and Economics 57(2014) 218-240

Lin. F, et.al, (2014), "The Relations Among Accounting Conservatism, Institutional Investors and Earnings Manipulation", Economic Modelling 37 (2014) 164-174.

Lins, Karl V. (2003). Equity Ownership and Firm value Emerging Markets. Journal of Financial and Quantitative Analysis. Vol. 38. No. 1 (March).

Manganarisa. P, Spathisa. C and Dasilas. A, (2015), The Effects of Mandatory IFRS Adoption and Conditional Conservatism on European Bank Values, Journal of International Accounting, Auditing and Taxation 24 (2015) 72-81

Penman,S., and X.Zhang. (2002). Accounting Conservatism, Quality of earnings,Stock returns.The Accounting Review

Sadidi, Mehdi, Ali Saghafi, and Shahin Ahmad. (2011). Accounting Conservatism and the Effect of Earning Quality on the Return of Assets and Stock Return.Journal of Accounting Knowledge.2(6).

Sekaran Uma, (2007) Research Methods For Business. Buku Satu, Edisis Empat. Salemba Empat, Jakarta.

Siregar, S. V. N., \& Utama, S. (2006). Pengaruh Struktur Kepemilikan, Ukuran Perusahaan, dan Praktik Corporate Gorvernance Terhadap Pengelolaan Laba (Earnings Management). The Indonesian Journal of Accounting Research, 9(3).

Xiaa D and Song Zhub, (2009), Corporate Governance and Accounting Conservatism in China, China Journal of Accounting Research, Vol 2 Issue 2.
Vafeas, N. and Afxentiou, Z. (1998). The Association Between the SEC's 1992 Compensation Disclosure Rule and Executive Compensation Policy Changes. Journal of Accounting and Public Policy 17(1). 